\title{
Associations of Low Environmental Exposure to Multiple Metals with Renal Tubular Impairment in Korean Adults
}

\author{
Hyungryul Lim', Ji-ae Lim ', Jong Hyuk Choi', Ho-jang Kwon', Mina Ha', Heon Kim² and Jung-duck Park ${ }^{3}$ \\ 'Department of Preventive Medicine, Dankook University College of Medicine, Cheonan, Korea \\ ${ }^{2}$ Department of Preventive Medicine, Chungbuk National University College of Medicine, Cheongju, Korea \\ ${ }^{3}$ Department of Preventive Medicine, Chung-ang University College of Medicine, Seoul, Korea
}

(Received December 1, 2015; Revised December 15, 2015; Accepted January 3, 2016)

\begin{abstract}
Recently several studies reported that the renal toxicity of lead $(\mathrm{Pb})$ and cadmium $(\mathrm{Cd})$ may exist in even a low level exposure. In terms of the deterioration of tubular function, it affects the loss of divalent metals and leads to other complications, so renal tubular effect of heavy metals should be well managed. Considering the exposure to heavy metals in reality, it is hard to find the case that human is exposed to only one heavy metal. We designed a cross-sectional study using Korean Research Project on the Integrated Exposure Assessment (KRIEFS) data to investigate the renal effects of multiple metal exposure in general population. We used blood $\mathrm{Pb}$ and urinary $\mathrm{Cd}$ as exposure measures, and urinary $\mathrm{N}$-acetyl- $\beta$-D-glucosaminidase (NAG) and $\beta_{2}$-microglobulin $\left(\beta_{2}-\mathrm{MG}\right)$ as renal tubular impairment outcome. We conducted linear regression to identify the association between each heavy metal and urinary NAG and $\beta_{2}$-MG. And then, we conducted linear regression including the interaction term. Of 1953 adults in KRIEFS (2010 2011), the geometric mean of blood $\mathrm{Pb}$ and urinary $\mathrm{Cd}$ concentration was $2.21 \mu \mathrm{g} / \mathrm{dL}$ (geometric $\mathrm{SD}=1.49 \mu \mathrm{g} / \mathrm{dL}$ ) and $1.08 \mu \mathrm{g} / \mathrm{g}$ cr (geometric $\mathrm{SD}=1.98 \mu \mathrm{g} / \mathrm{g}$ cr), respectively. In urinary $\mathrm{Cd}$, the strength of the association was also high after adjusting (urinary NAG: $\beta=0.44, p<0.001$; urinary $\beta_{2}$-MG: $\beta=0.13, p=0.002$ ). Finally, we identified the positive interactions for the two renal biomarkers. The interaction effect of the two heavy metals of $\beta_{2}$-MG was greater than that of NAG. It is very important in public health perspective if the low level exposure to multiple heavy metals has an interaction effect on kidney. More epidemiological studies for the interaction and toxicological studies on the mechanism are needed.
\end{abstract}

Key words: Lead, Cadmium, Interaction, NAG, $\beta_{2}-\mathrm{MG}$, Renal tubular impairment

\section{INTRODUCTION}

Up to now, the acute and chronic effects of the exposure to heavy metals caused by working environments or environmental pollution have been well-known, and general people well recognize the risk of the excessive exposure to heavy metals. However, the effect of the exposure to heavy metals with low concentration as well as high one has been reported, and it tends to strengthen the management of the chronic exposure to low level heavy metals. Thus, U.S. Centers for Disease Control and Prevention (CDC) set $5 \mu \mathrm{g} /$

Correspondence to: Ho-jang Kwon, Department of Preventive Medicine, Dankook University College of Medicine, Cheonan 330714, Korea

E-mail: hojang@dankook.ac.kr

This is an Open-Access article distributed under the terms of the Creative Commons Attribution Non-Commercial License (http:// creativecommons.org/licenses/by-nc/3.0) which permits unrestricted non-commercial use, distribution, and reproduction in any medium, provided the original work is properly cited.
$\mathrm{dL}$ in blood, which is the top $2.6 \%$ of the children from $1 \sim 5$ years of age, as a new lead $(\mathrm{Pb})$ reference level by removing the existing reference of blood $10 \mu \mathrm{g} / \mathrm{dL}$ because the evidence of the previous $\mathrm{Pb}$ threshold value is insufficient (1). In addition, Joint FAO/WHO Expert Committee on Food Additives (JECFA) withdraw the provisional tolerable weekly intake (PTWI) of $25 \mu \mathrm{g} / \mathrm{kg}$ body weight/week, which was the proposed $\mathrm{Pb}$ reference in 2010 (2). In case of cadmium (Cd), European Food Safety Authority (EFSA) newly proposed PTWI of $2.5 \mu \mathrm{g} / \mathrm{kg}$ body weight/week that the urinary $\mathrm{Cd}$ concentration does not exceed $1 \mu \mathrm{g} / \mathrm{g}$ creatinine in 2009 (3).

The exposure level of heavy metals of Korean adults tends to decrease every year, but is still high compared with that of foreign countries. According to the first Korean National Environmental Health Survey (KNEHS, 2009 2011) and the fifth Korea National Health and Nutrition Examination Survey (KNHANES), the blood Pb concentration of Korean adults was $1.77 \mu \mathrm{g} / \mathrm{dL}$ and $2.24 \mu \mathrm{g} / \mathrm{dL}$ for each, and the blood $\mathrm{Cd}$ concentration was $1.03 \mu \mathrm{g} / \mathrm{L}$ from 
KNHANES and the urinary Cd concentration was $0.66 \mu \mathrm{g} /$ $\mathrm{g}$ creatinine from KNEHS $(4,5)$. According to the U.S. NHANES IV (2011 2012), the American adults aged 19 and over had the blood $\mathrm{Pb}$ concentration of $0.97 \mu \mathrm{g} / \mathrm{dL}$, the blood $\mathrm{Cd}$ concentration of $0.28 \mu \mathrm{g} / \mathrm{L}$, and the urinary $\mathrm{Cd}$ concentration of $0.16 \mu \mathrm{g} / \mathrm{g}$ creatinine (6). The American values are lower than the Korean ones. In case of German Environment Survey (GerES III), German adults from 18 69 years of age had the blood $\mathrm{Pb}$ concentration of $3.07 \mu \mathrm{g} /$ $\mathrm{L}$, the blood $\mathrm{Cd}$ concentration of $0.44 \mu \mathrm{g} / \mathrm{L}$, and the urinary Cd concentration of $0.24 \mu \mathrm{g} / \mathrm{g}$ creatinine (7). The German values of cadmium are also lower than the Korean ones.

Both $\mathrm{Cd}$ and $\mathrm{Pb}$ cause the deterioration of tubular function which significantly affects the loss of essential divalent metals. Thus, its health effect should be well managed in addition to the degradation of glomerular function. Most representative and well-known renal tubular biomarkers are $\mathrm{N}$-acetyl- $\beta$-D-glucosaminidase (NAG) and $\beta_{2}$-microglobulin $\left(\beta_{2}-\mathrm{MG}\right)$. Urinary NAG is the lysosomal enzyme that much exists in proximal kidney tubule. It is very sensitive biomarker that renal tubular impairment can be easily and noninvasively measured at a low cost (8). $\beta_{2}$-MG is a single-chain small polypeptide and is flowed with tubular fluid through glomerular filtration. It is normal that $\beta_{2}-\mathrm{MG}$ is reabsorbed in proximal tubule and that its small quantity is excreted. If renal tubular cell is injured, the excretion increases. Thus, $\beta_{2}-\mathrm{MG}$ is also used as a biomarker that is highly used, and it is very sensitive (9). Even in kidney damage caused by heavy metals such as $\mathrm{Pb}$ and $\mathrm{Cd}$, the excretion of urinary NAG and $\beta_{2}$-MG may increase (10).

In relation to this, recently, several epidemiologic studies reported the significant relation between low level urinary $\mathrm{Cd}$ caused by environmental exposure instead of occupational exposure and urinary NAG and $\beta_{2}-\mathrm{MG}$ in the general population. The range of geometric means of urinary $\mathrm{Cd}$ of those studies is $0.6 \sim 4.5 \mu \mathrm{g} / \mathrm{g}$ creatinine (11-15).

Meanwhile, considering the exposure to heavy metals in reality, it is hard to find the case that human is exposed to only one heavy metal. But under the situation, the studies that apply the exposure to multiple heavy metals have been hardly conducted. Some studies reported the concurrent exposure to heavy metals may have additive or synergistic interaction to glomerular or tubular functional loss, and also some epidemiological studies reported that interaction or, reversely, antagonistic effect (16-19).

The aim of this study is to find the relation between the low level exposure to $\mathrm{Cd}$ and $\mathrm{Pb}$ in the general population and urinary NAG and $\beta_{2}-\mathrm{MG}$, and to find the interaction effect when humans are exposed to both two heavy metals.

\section{MATERIALS AND METHODS}

This study was approved by the ethics committee of Dankook University Hospital (DKUHIRB2010-04-0093,

\section{DKUHIRB2011-03-0086).}

Study participants. The participants of this study were the people in Korean Research Project on the Integrated Exposure Assessment to Hazardous Materials for Food Safety (KRIEFS), conducted from 2010 to 2012 by Korean Ministry of Food and Drug Safety. This study supplements the shortage of KNHANES and KNEHS, and gives the comprehensive research on dietary intake of many types of noxious substances in addition to heavy metals and the effect on human health specific to those substances. The participants were selected from 15 cities except Jeju-do in Korea. Their selection method was the square root allocation based on the population composition after the allocation of the minimum sample size by region, gender, and age to extract household in 102 Eups, Myeons, and Dongs. Total 4,867 people joined this study. Among them, the number of the people at 19 or higher is 2,118 . The participants had physical measurement and examination, and dietary questionnaire was conducted. In addition, their blood, 12-hr urine, and spot urine were collected (20).

Measurement of blood $\mathbf{P b}$ and urinary $\mathbf{C d}$. $\mathrm{Pb}$ was measured in the blood, and Cd was in the blood and the 12hr urine. The 12-hr urine was collected from the time after the dinner the day before the survey date to the morning of the survey date. Urine sample was collected by using a plastic cup, put in a plastic bag, and stored in a cool space until the survey morning. The blood sample collected was put in a heavy metal ethylene diamine acetic acid (EDTA) tube and well mixed with anticoagulant. The sample was stored and transported at $4^{\circ} \mathrm{C}$.

The analysis of $\mathrm{Pb}$ and $\mathrm{Cd}$ in the blood was performed by using Graphite Furnace Atomic absorption Spectrometer (GF-AAS) manufactured by Thermo (Cambridge, UK). And the analysis of $\mathrm{Cd}$ in the urine was performed by using GF-AAS manufactured by Varian. The sample for the analysis was homogenized by using a roller mixer. With $0.15 \mathrm{~mL}$, the diluted solution of $0.2 \%$ Tirton X-100, $1.2 \mathrm{~mL}$ and the tertiary distilled water, $0.15 \mathrm{~mL}$, were added and well mixed, and analyzed by using an atomic absorption spectrometer (AAS). For data analysis, the $\mathrm{Pb}$ in the blood and the $\mathrm{Cd}$ in the urine were used.

Measurement of adverse renal biomarkers: Urinary NAG and $\beta_{2}$-MG. Urinary NAG activity was measured by using NAG Quantitative Kit (Shionogi, Osaka, Japan). After storing a synthetic substrate solution $(1 \mathrm{~mL})$ at $37^{\circ} \mathrm{C}$ for five minutes, the solution was mixed with the supernatant of the urine samples $(50 \mathrm{~mL})$ received after centrifugation. After storing it at $37^{\circ} \mathrm{C}$ for $15 \mathrm{~min}$, stopping solution $(2 \mathrm{~mL})$ was added to and mixed with it. By using a spectrophotometer, its fluorescence intensities were measured with a wavelength of $580 \mathrm{~nm}(13,14)$. 
Urinary $\beta_{2}$-MG was measured by using Enzygnost $\beta_{2}$ MG Micro Kit (Behring Institute, Mannheim, Germany). Its method used the principle of solid phase enzyme-linked immunosorbent assay (ELISA). Monoclonal anti- $\beta_{2}-\mathrm{MG}$ antibody and anti-2-MG-horseradish peroxidase conjugate solution were used. After that, color intensities were measured with a wavelength of $450 \mathrm{~nm}$ by using a spectrophotometer $(13,14)$.

Other covariates. The height and weight of the participants were directly measured by the researchers of this study to calculate the body mass index. With $18.5,25$, and
30 set as a cut-off value, the participants were divided into four groups. The questionnaires were completed by direct interviews with the researchers. In case of smoking, questions like "Have you smoked five packs of cigarettes (100 cigarettes)?" and "Do you still smoke?" divide into the groups of former smokers, current smokers, and nonsmokers. In case of drinking, for the question of "How often do you have a drink containing alcohol?", there are 5 answers, "Never in 1 year", "Less than once a month", "Once a month", "Two-four times a month", "Two-three times a week", and "Four or more times a week". For household income, the participants were divided into eight groups. For

Table 1. General characteristics, blood or urinary heavy metal concentration, and adverse renal effect indicators of study participants

\begin{tabular}{|c|c|c|c|c|c|}
\hline Total $(n=1953)$ & $\mathrm{N}$ & $\%$ & Mean (SD) & Median & $90^{\text {th }}$ percentile \\
\hline \multicolumn{6}{|l|}{ Sex } \\
\hline Male & 842 & 43.1 & & & \\
\hline Female & 1111 & 56.9 & & & \\
\hline Age (Yr) & & & $45.3(14.7)$ & & \\
\hline$<25$ & 243 & 12.4 & & & \\
\hline $25 \sim 34$ & 224 & 11.5 & & & \\
\hline $35 \sim 44$ & 432 & 22.1 & & & \\
\hline $45 \sim 54$ & 470 & 24.1 & & & \\
\hline $55 \sim 64$ & 409 & 20.9 & & & \\
\hline$\geq 65$ & 175 & 9.0 & & & \\
\hline BMI (Body mass index, $\mathrm{kg} / \mathrm{m}^{2}$ ) & & & $24.1(3.4)$ & & \\
\hline$<18.5$ & 56 & 2.9 & & & \\
\hline $18.5 \sim 24.9$ & 1188 & 60.8 & & & \\
\hline $25.0 \sim 29.9$ & 623 & 31.9 & & & \\
\hline$\geq 30$ & 86 & 4.4 & & & \\
\hline \multicolumn{6}{|l|}{ Smoking status } \\
\hline Non-smoker & 1256 & 64.3 & & & \\
\hline Ex-smoker & 307 & 15.7 & & & \\
\hline Current smoker & 390 & 20.0 & & & \\
\hline \multicolumn{6}{|l|}{ Alcohol drinking } \\
\hline Never & 482 & 24.7 & & & \\
\hline Once or less than once a month & 528 & 27.0 & & & \\
\hline $2 \sim 4$ times a month & 460 & 23.6 & & & \\
\hline More than twice a week & 483 & 24.7 & & & \\
\hline \multicolumn{6}{|l|}{ Household income $(\mathrm{KRW} \times \mathbf{1 0 , 0 0 0})$} \\
\hline$<200$ & 792 & 40.6 & & & \\
\hline$\geq 200,<300$ & 430 & 22.0 & & & \\
\hline$\geq 300,<400$ & 327 & 16.7 & & & \\
\hline$\geq 400$ & 404 & 20.7 & & & \\
\hline \multicolumn{6}{|l|}{ Education level } \\
\hline Below middle school & 584 & 29.9 & & & \\
\hline Below high school & 655 & 33.5 & & & \\
\hline College or higher & 714 & 36.6 & & & \\
\hline \multicolumn{6}{|l|}{ Medical history } \\
\hline Hypertension (Yes) & 297 & 15.2 & & & \\
\hline Diabetes (Yes) & 116 & 5.9 & & & \\
\hline Blood Pb $(\mu \mathrm{g} / \mathrm{dL})$ & & & $2.21(1.49)^{\mathrm{a}}$ & 2.20 & 3.66 \\
\hline Urinary $\mathbf{C d}(\mu \mathrm{g} / \mathrm{g}$ creatinine $)$ & & & $1.08(1.98)^{\mathrm{a}}$ & 1.14 & 2.50 \\
\hline Urinary NAG activity (Unit/g creatinine) & & & $4.01(2.78)^{\mathrm{a}}$ & 4.03 & 14.32 \\
\hline Urinary $\beta_{2}$-microglobulin $(\mu \mathrm{g} / \mathrm{g}$ creatinine) & & & $51.4(2.64)^{\mathrm{a}}$ & 54.44 & 151.45 \\
\hline
\end{tabular}

${ }^{a}$ Geomatric means and standard deviations were calculated. 
education level, there were nine groups. These were regrouped considering frequency (Table 1). For the past medical history of high blood pressure and diabetes, "Have you every diagnosed the following disease by doctors?" was asked and its answers were "None", "I recovered from the diseases", "I still have the disease". They were re-grouped and divided into dichotomous variables, yes or no.

Statistical analysis. The distribution of the gender, age, and other covariates of the participants, which would be included in the main analyses, was examined. We designated predictor variables as $\mathrm{Pb}$ in the blood and $\mathrm{Cd}$ in the urine, and outcome variables as urinary NAG and $\beta_{2}-\mathrm{MG}$ and calculated the geometric mean and standard deviation, median, and 90 percentile of those variables. In addition, the correlation coefficient was calculated through the spearman correlation test to identify the correlation between the four variables. Before identifying the interaction effect between $\mathrm{Pb}$ and $\mathrm{Cd}$, we conducted linear regression to identify the association between each heavy metal and urinary creatinine adjusted NAG and $\beta_{2}-\mathrm{MG}$ (unadjusted and adjusted for covariates). Finally, we checked interaction effect of two metals in terms of urinary NAG and $\beta_{2}$-MG. We applied those metals and their interaction term (blood $\mathrm{Pb} \times$ urinary $\mathrm{Cd}$ ) in one linear model. To decrease right skewness and improve the explanation of the model, we used the decimal logarithm transformed predictor variables and the outcome variables. And to see the effect of one metal modified by the other, we divided the data by concentration quartile groups of counterpart metal, and in each data we conducted linear regression and checked the coefficient of one. Covariates like gender, age, body mass index (BMI), smoking, alcohol drinking, household income, past medical history for high blood pressure and diabetes were applied to each model for adjusting. All statistical analyses were performed using $\mathrm{R}$ ver. 3.1.3.

\section{RESULTS}

Among the 2,118 adults who were recruited from 2010 to 2011, after excluding those who have kidney disease $(n=$ 47) and have missing data 1,953 were finally included in our analyses. There is no significant difference between the proportion and number overview of each variable before and after excluding those who have missing values. Men accounted for $43.1 \%(n=842)$ and women for $56.9 \%(n=$ 1111) among the participants. Their age ranged from 18 to 83. The average age was 45.5 . About $20.0 \%$ participants were a current smoker. In terms of the past medical history, $15.2 \%(n=297)$ people had high blood pressure and 5.9\% $(\mathrm{n}=116)$ had diabetes. The geometric mean of the $\mathrm{Pb}$ concentration in the blood was $2.21 \mu \mathrm{g} / \mathrm{dL}$ (geometric $\mathrm{SD}=1.49$ $\mu \mathrm{g} / \mathrm{dL}$ ), and that of the $\mathrm{Cd}$ concentration in the urine was $1.08 \mu \mathrm{g} / \mathrm{g}$ cr (geometric $\mathrm{SD}=1.98 \mu \mathrm{g} / \mathrm{g}$ cr). The geometric mean of the urinary NAG concentration and that of $\beta_{2}-\mathrm{MG}$ concentration were $4.01 \mathrm{Unit} / \mathrm{g}$ creatinine (geometric $\mathrm{SD}=$ 2.78 ) and $51.4 \mu \mathrm{g} / \mathrm{g}$ cr (geometric $\mathrm{SD}=2.64$ ), respectively. There were lower than the clinically significant level (Table 1 ).

The correlation between four predictor and outcome variables was identified with the spearman correlation coefficient. The coefficient between Blood $\mathrm{Pb}$ and urinary $\mathrm{Cd}$ was 0.13 and their correlation was weak. In terms of the correlation between heavy metals and two adverse renal biomarkers, urinary $\mathrm{Cd}$ was more positively associated than blood $\mathrm{Pb}$, and the correlation of NAG $(\mathrm{r}=0.33)$ has a higher coefficient than $\beta_{2}-\mathrm{MG}(\mathrm{r}=0.19)$ in urinary $\mathrm{Cd}($ Table 2$)$.

Table 2. Spearman correlation coefficient between predictor and outcome variables

\begin{tabular}{lcccc}
\hline \hline & Blood $\mathrm{Pb}$ & Urinary Cd & Urinary NAG & Urinary $\beta_{2}$-MG \\
\hline Blood $\mathrm{Pb}(\mu \mathrm{g} / \mathrm{dL})$ & 1 & - & - & - \\
Urinary $\mathrm{Cd}(\mu \mathrm{g} / \mathrm{g}$ creatinine $)$ & 0.13 & 1 & - & - \\
Urinary $\mathrm{NAG}($ Unit/g creatinine $)$ & 0.13 & 0.33 & 1 & - \\
Urinary $\beta_{2}$-MG $(\mu \mathrm{g} / \mathrm{g}$ creatinine) & 0.05 & 0.19 & 0.24 & 1 \\
\hline
\end{tabular}

Table 3. Linear regression for each lead, cadmium, and mercury concentrations and each renal impairment indexes

\begin{tabular}{|c|c|c|c|c|c|c|}
\hline \multirow{2}{*}{ Predictor variable } & \multicolumn{3}{|c|}{ Crude model } & \multicolumn{3}{|c|}{ " Adjusted model $^{\mathrm{b}}$} \\
\hline & $\beta$ & $\mathrm{SE}$ & p-value & $\beta$ & SE & p-value \\
\hline & \multicolumn{6}{|c|}{ Urinary NAG (IU/g creatinine) $)^{\mathrm{a}}$} \\
\hline Blood $\mathrm{Pb}(\mu \mathrm{g} / \mathrm{dL})^{\mathrm{a}}$ & 0.31 & 0.06 & $<0.001$ & 0.09 & 0.07 & 0.320 \\
\hline \multirow[t]{2}{*}{ Urinary $\mathrm{Cd}(\mu \mathrm{g} / \mathrm{g} \text { creatinine })^{\mathrm{a}}$} & 0.45 & 0.03 & $<0.001$ & 0.44 & 0.04 & $<.0001$ \\
\hline & \multicolumn{6}{|c|}{ Urinary $\beta_{2}-\mathrm{MG}(\mu \mathrm{g} / \mathrm{g} \text { creatinine })^{\mathrm{a}}$} \\
\hline Blood $\mathrm{Pb}(\mu \mathrm{g} / \mathrm{dL})^{\mathrm{a}}$ & 0.12 & 0.06 & 0.029 & 0.01 & 0.07 & 0.844 \\
\hline Urinary $\mathrm{Cd}(\mu \mathrm{g} / \mathrm{g} \text { creatinine })^{\mathrm{a}}$ & 0.24 & 0.03 & $<.0001$ & 0.13 & 0.04 & 0.002 \\
\hline
\end{tabular}

${ }^{\mathrm{a} A l l}$ predictor and outcome variables were decimal logarithm transformed.

${ }^{\mathrm{b}}$ Adjusted for age, sex, BMl, household income, smoking, alcohol drinking, past medical history (hypertension, diabetes). 
Table 4. Multiple linear regression with interaction term between blood lead and urinary cadmium

\begin{tabular}{|c|c|c|c|c|c|c|}
\hline \multirow{2}{*}{ Predictor variable } & \multicolumn{3}{|c|}{ Crude model } & \multicolumn{3}{|c|}{ Adjusted model $^{\mathrm{b}}$} \\
\hline & $\beta$ & SE & p-value & $\beta$ & $\mathrm{SE}$ & p-value \\
\hline & \multicolumn{6}{|c|}{ Urinary NAG (IU/g cr) ${ }^{\mathrm{a}}$} \\
\hline Blood $\mathrm{Pb}(\mu \mathrm{g} / \mathrm{dL})^{\mathrm{a}}$ & 0.19 & 0.06 & $<0.001$ & -0.01 & 0.07 & 0.918 \\
\hline Urinary $\mathrm{Cd} / \mathrm{cr}(\mu \mathrm{g} / \mathrm{g} \text { creatinine })^{\mathrm{a}}$ & 0.33 & 0.07 & $<0.001$ & 0.35 & 0.08 & $<0.001$ \\
\hline \multirow[t]{2}{*}{ Interaction } & 0.34 & 0.19 & 0.082 & 0.25 & 0.19 & 0.196 \\
\hline & \multicolumn{6}{|c|}{ Urinary $\beta_{2}-\mathrm{MG}(\mu \mathrm{g} / \mathrm{g} \mathrm{cr})^{\mathrm{a}}$} \\
\hline Blood $\mathrm{Pb}(\mu \mathrm{g} / \mathrm{dL})^{\mathrm{a}}$ & 0.06 & 0.05 & 0.298 & -0.02 & 0.07 & 0.721 \\
\hline Urinary $\mathrm{Cd} / \mathrm{cr}(\mu \mathrm{g} / \mathrm{g} \text { creatinine })^{\mathrm{a}}$ & 0.02 & 0.07 & 0.768 & -0.12 & 0.08 & 0.126 \\
\hline Interaction & 0.66 & 0.19 & $<0.001$ & 0.73 & 0.20 & $<0.001$ \\
\hline
\end{tabular}

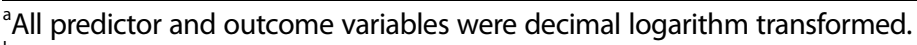

${ }^{\mathrm{b}}$ Adjusted for age, sex, BMI, household income, smoking, alcohol drinking, past medical history (hypertension, diabetes).

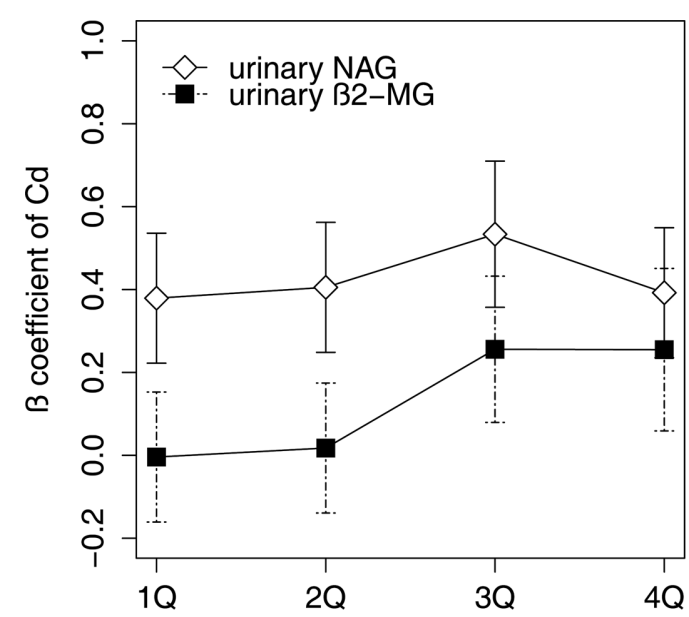

Quartile group of $\mathrm{Pb}$ concentration

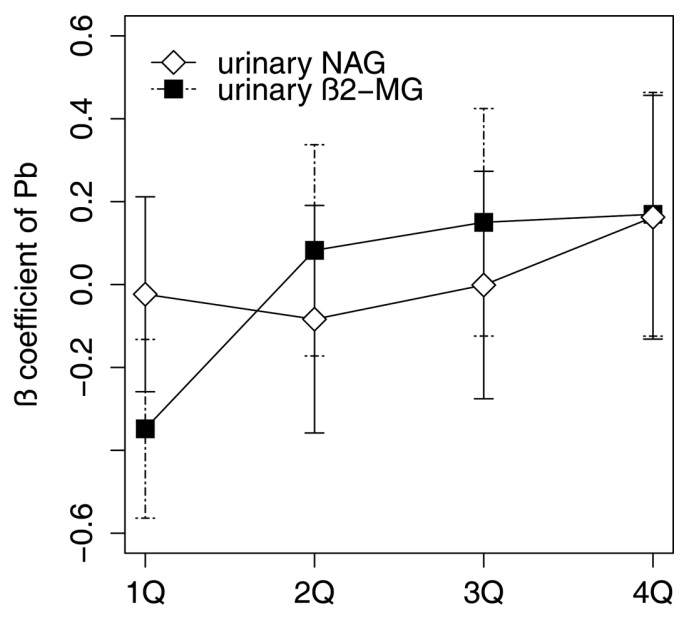

Quartile group of Cd concentration

Fig. 1. Effect coefficient of urinary $\mathrm{Cd}$ and blood Pb on urinary NAG and $\beta_{2}-\mathrm{MG}$ modified by the concentration of the counterpart metal. The two figures show the $\beta$ coefficients of urinary $\mathrm{Cd}$ (left) and blood Pb (right) on urinary NAG (white rhomb), and $\beta_{2}-\mathrm{MG}$ (black square) using the multiple linear regression model adjusted for age, sex, BMI, household income, smoking, alcohol drinking, and past medical history in the data stratified by quartile groups of the concentration of counterpart metal (1Q: $1^{\text {st }}$ quartile group, $2 \mathrm{Q}: 2^{\text {nd }}$ quartile group, 3Q: $3^{\text {rd }}$ quartile group, $4 \mathrm{Q}: 4^{\text {th }}$ quartile group).

In the unadjusted linear regression model, the concentration of the blood $\mathrm{Pb}$ and the urinary $\mathrm{Cd}$ highly affected both urinary NAG and $\beta_{2}$-MG. However, in the model after adjusting, each effect was attenuated. However, all models had a positive coefficient value. In case of urinary $\mathrm{Cd}$, the strength of the association was also high after adjusting (urinary NAG: $\beta=0.44, \mathrm{p}<0.001$; urinary $\beta_{2}$-MG: $\beta=$ $0.13, \mathrm{p}=0.002)($ Table 3$)$.

Finally, in the linear regression model with blood $\mathrm{Pb}$, urinary $\mathrm{Cd}$, and their interaction term, the positive interactions for the two renal biomarkers were identified. In case of urinary NAG, the synergistic interaction of the two heavy metals was attenuated $(\beta=0.34, p=0.082$ to $\beta=0.25, p=$ $0.196)$ after adjusting. However, in case of $\beta_{2}-\mathrm{MG}$, the interaction was reinforced $(\beta=0.66, p<0.001$ to $\beta=0.73, p<$ $0.001)$. The interaction effect of the two heavy metals of $\beta_{2}$ MG was greater than that of NAG (Table 4). In stratified data analyses, we found the effect modification of $\mathrm{Pb}$ and $\mathrm{Cd}$ exposure through $\mathrm{Cd}$ and $\mathrm{Pb}$ concentration quartile groups. We could find more eminent increases of effect on $\beta_{2}$-MG than NAG (Fig. 1).

\section{DISCUSSION}

In brief, the concentrations of blood $\mathrm{Pb}$ and urinary $\mathrm{Cd}$ were positively associated with urinary NAG and $\beta_{2}-\mathrm{MG}$ in general adults. In addition, we identified the synergism between two metals in the concurrent exposure, and that effect was stronger for $\beta_{2}$-MG. That is, when $\mathrm{Pb}$ and $\mathrm{Cd}$ were excreted through the kidney, the effect of the injury of renal tubular cells caused by concurrent exposure was larger than the combination of each effect. It can be also thought that the effect of one metal is reinforced as the other metal exposure is increased. 
If a human is chronically exposed to heavy metals, they exist in the blood in combination with protein in addition to free form. They are combined with albumin and with the metallothioneins and glutathione in the blood, which are created to prevent the toxicity of heavy metals in liver and kidney cells. Through the filtration in renal glomeruli, they affect the glomerular function, and also are uptaken through sodium-amino acid cotransporter or endocytosis to renal tubular cell. In addition to the free form heavy metals, conjugated forms can be also uptaken in tubular cell and released in the free form, resulting in the damage of the tubular function $(10,21)$.

The mechanism of the reinforcement of the renal tubular effect by the coexposure of $\mathrm{Cd}$ and $\mathrm{Pb}$ is not yet clearly identified. It is thought that the $\mathrm{Pb}$ binding proteins (PbBPs), metallothionein, glutathione, and heat shock protein (HSP) may act as an important regulator (16). In addition, the similarity of the mechanisms and the action sites of $\mathrm{Cd}$ and $\mathrm{Pb}$ also may play a role of their interaction. With the binding with sulfonyl-group containing enzymes, sequentially reactive oxidative stress is generated, resulting in cell injury $(17,19)$.

In multiple linear regression models for one metal effect, the effect of urinary $\mathrm{Cd}$ was stronger. Our results are consistent with the result of the previous studies. In particular, in case of $\beta_{2}-\mathrm{MG}$, after adjusted for other covariates the effect of blood $\mathrm{Pb}$ in the model almost disappeared $(\beta=0.01, \mathrm{p}=$ $0.844)$, but the effect of urinary $\mathrm{Cd}$ after adjusted was still strong $(\beta=0.13, p=0.002)$. It supports that $\beta_{2}-\mathrm{MG}$ is a more specific biomarker for the $\mathrm{Cd}$ effect (17). It is also well explained considering the main target organ of $\mathrm{Cd}$ is known to kidney.

Several epidemiological studies considering multiple heavy metals exposure in workers were reported. In a study targeting 57 non-ferrous metal smelter workers in France, the co-exposure was considered. The mean of blood $\mathrm{Pb}$ was $38.71 \mu \mathrm{g} / \mathrm{dL}$, and that of urinary $\mathrm{Cd}$ was $2.5 \mu \mathrm{g} / \mathrm{g}$ creatinine. They tried to identify the effect of the co-exposure of $\mathrm{Pb}$ and $\mathrm{Cd}$ on urinary $\alpha$-glutathione S-transferases ( $\alpha \mathrm{GST}$ ) using two-way ANOVA. $\alpha$ GST was an early marker that exists in the proximal tubule. If it is damaged, that enzymes are discharged to tubular fluid. It was found that the exposure to $\mathrm{Pb}$ had a main effect on the people co-exposed. But the interaction between them was not statistically significant (22).

In a cross-section study on the co-exposure of $\mathrm{Pb}$ and $\mathrm{Cd}$, targeting 122 Belgian metallurgy workers, the study identified the association between those two metal and five renal tubular biomarkers. The median of the urinary $\mathrm{Cd}$ of participants was $0.5 \mu \mathrm{g} / \mathrm{g}$ creatinine, and that of the blood $\mathrm{Pb}$ was $15.85 \mu \mathrm{g} / \mathrm{dL}$. They made binary variable about $\mathrm{Pb}$ exposure (over 75 percentile or not). It was found that the effect of the $\mathrm{Cd}$ in the blood and urine on the urinary NAG was reinforced in highly $\mathrm{Pb}$ exposure group, and they had interac- tion effect $(\beta=0.39, \mathrm{p}=0.02$ for blood $\mathrm{Cd} \times \mathrm{Pb}$ group, $\beta=$ $0.84, \mathrm{p}=0.001$ for urinary $\mathrm{Cd} \times \mathrm{Pb}$ group). In terms of the interaction with $\beta_{2}-\mathrm{MG}$, there was no significant effect (19). The result is contrasted with that of our study that we reported the synergistic effect for $\beta_{2}$-MG. However, in case of NAG, the result is consistent with ours.

In a study targeting Korean 684 lead worker, the association between the exposure to thallium, antimony, $\mathrm{Cd}$ and $\mathrm{Pb}$ and glomerular filtration rate (GFR) and NAG. The median of urinary $\mathrm{Cd}$, antimony, thallium and blood $\mathrm{Pb}$ was $0.83 \mu \mathrm{g} / \mathrm{g}$ creatinine, $0.36 \mu \mathrm{g} / \mathrm{g}$ creatinine, $0.39 \mu \mathrm{g} / \mathrm{g}$ creatinine, and $21.5 \mu \mathrm{g} / \mathrm{dL}$, respectively. By putting those metals together in multiple linear regression models, it was found that the effect of the one metal was attenuated by other metals' effects, and the author suggest that it is needed to be cautious about the interpretation of the single metal exposure analysis with low concentration. However, this study did not conduct the interaction in detail (23).

The effects of multiple metal exposure were also investigated in US general population. In a study, published in 2009 , on the interaction effect of reduced estimated GFR (eGFR) $\left(<60 \mathrm{~mL} / \mathrm{min} / 1.73 \mathrm{~m}^{2}\right)$ and microalbuminuria $(\geq 30$ $\mathrm{mg} / \mathrm{g}$ creatinine) in case of the co-exposure of blood $\mathrm{Cd}$ and blood Pb in U.S. NHANES (1999 2006) participants, when 2 log-transformed metals were modeled to multiple linear regression with their interaction term, there was a strong interaction with microalbuminuria $(p=0.003)$, but weak interaction with reduced eGFR $(p=0.17)$. It is meaningful that the participants of the study were 14,778 American who were exposed to the heavy metals at low level (geometric mean: blood $\mathrm{Pb}=1.58 \mu \mathrm{g} / \mathrm{dL}$, blood $\mathrm{Cd}=0.41 \mu \mathrm{g} /$ L) and have representativeness (17). Those two points are the same as in our study. Even though this American study did not use the same renal tubular marker, the result of the synergistic interaction for microalbuminuria supports out research result because microalbuminuria can be a marker that reflects renal tubular impairment.

A study on the interaction of the renal function of $\mathrm{Pb}$ and $\mathrm{Cd}$ through structural equation modeling (SEM) was preceded. It targeted 7,236 people and also used the U.S. NHANES (1999-2008) data. The median of blood $\mathrm{Pb}$ was $1.3 \mu \mathrm{g} / \mathrm{dL}$, that of blood $\mathrm{Cd} 0.30 \mu \mathrm{g} / \mathrm{L}$, and that of urine $\mathrm{Cd}$ $0.22 \mathrm{ng} / \mathrm{mL}$. In the modeling, the predicted renal function score represented the four measurements, creatinine clearance, blood urea nitrogen (BUN), serum creatinine, and the ratio of urine albumin to urine creatinine. Serum $\mathrm{Cd}$ and serum Pd had synergistic interaction for renal effect (18). This result is consistent about glomerular function to the U.S. NHANES study of Navas-Acien et al. (17).

Our study is the first one that identified the association between low level $\mathrm{Pb}$ and $\mathrm{Cd}$ exposure and urinary NAG and $\beta_{2}-\mathrm{MG}$ through the national wide data that can represent Korea. In addition, we found the interaction effect in co-exposure of those two metals, so can add the evidence 
on this interaction.

It is very important in public health perspective that the low level exposure to multiple heavy metals has an interaction effect. General population is exposed to heavy metals almost orally. According to the material of Korean Ministry of Food and Drug Safety in 2010, 86.79\% people aged between 20 and 64 are exposed to $\mathrm{Pb}$, and as many as $95.5 \%$ is to $\mathrm{Cd}$ from food. Vegetables and white rice make the largest contribution to the exposure to $\mathrm{Pb}$ and $\mathrm{Cd}$, respectively, in food group (24). Considering the situation, it can be thought that the low exposure of general population is chronic over a lifetime. If the reduction in the exposure to only one heavy metal by food ingestion decrease the interaction effect of the co-exposure with the others as well as its own adverse effect, it will be economically profitable.

We have several limitations. First this study cannot reflect the effect of the co-exposure of a large number of other heavy metals and noxious substances. Wang and Fowler suggested it needs to introduce the Omics technique that can identify the general exposure and the effect of the exposure on human body (16).

Second, our study design is a cross-sectional study. Temporality is not clear, therefore our study cannot represent the causal relationship, but can identify the association. However, as the participants are the group of general people with low exposure, it is hard to say that the subtle renal tubular injury at an early stage increases the body burden of heavy metals.

Third, in terms of the modeling of the interaction effect, we performed statistical analysis and identified the coefficient by just adding interaction term to a linear model. It reflects multiplicative interaction, but is not about additive interaction. Nevertheless, in case of $\beta_{2}-\mathrm{MG}$, p-value was $<0.001$, and NAG was 0.196. It is thought that there is more than additive interaction, but the statistical analysis for the additive interaction of the exposure to the two heavy metals will be helpful to well understand the mechanism of the interaction.

In conclusion, we found that there is an interaction effect of $\mathrm{Pb}$ and $\mathrm{Cd}$ exposure on urinary NAG and $\beta_{2}$-MG. More epidemiological studies for the interaction and toxicological studies on the mechanism are needed.

\section{ACKNOWLEDGEMENTS}

We thank all of the participating survey subjects and participating researchers.

This research was supported by the Korea Food \& Drug Administration in 2014 (13162MFDS778).

\section{REFERENCES}

1. Burns, M.S. and Gerstenberger, S.L. (2014) Implications of the new Centers for Disease Control and Prevention blood lead reference value. Am. J. Public Health, 104, e27-33.

2. Joint FAO/WHO Expert Committee on Food Additives (JECFA). (2010) Evaluation of certain food additives and contaminants (Seventy-first report). WHO Tech. Rep. Ser., 960.

3. EFSA CONTAM Panel (EFSA Panel on Contaminants in the Food Chain). (2009) Cadmium in food - Scientific opinion of the Panel on Contaminants in the Food Chain. EFSA J., 980, 1-139.

4. Son, J.Y., Lee, J., Paek, D. and Lee, J.T. (2009) Blood levels of lead, cadmium, and mercury in the Korean population: results from the Second Korean National Human Exposure and Bio-monitoring Examination. Environ. Res., 109, 738744.

5. Korean Centers for Disease Control and Prevention. (2011) 2010 National Health Statistics, Korean National Health and Nutrition Examination Survey (KNHANES). First year.

6. U.S. Centers for Disease Control and Prevention. (2015) Fourth national report on human exposure to environmental chemicals.

7. Becker, K., Kaus, S., Krause, C., Lepom, P., Schulz, C., Seiwert, M. and Seifert, B. (2002) German Environmental Survey 1998 (GerES III): environmental pollutants in blood of the German population. Int. J. Hyg. Environ. Health, 205, 297308.

8. Skálová, S. (2005) The diagnostic role of urinary N-acetylbeta-D-glucosaminidase (NAG) activity in the detection of renal tubular impairment. Acta Med. (Hradec Kralove), 48, 75-80.

9. Zeng, X., Hossain, D., Bostwick, D.G., Herrera, G.A. and Zhang, P.L. (2014) Urinary beta2-Microglobulin Is a Good Indicator of Proximal Tubule Injury. J. Biomarkers, 2014, 492838.

10. Klaassen, C. (2013) Casarett \& Doull's Toxicology: The Basic Science of Poisons (Eighth edition). McGraw-Hill Education, pp. 990-995.

11. Huang, M., Choi, S.J., Kim, D.W., Kim, N.Y., Bae, H.S., Yu, S.D., Kim, D.S., Kim, H., Choi, B.S., Yu, I.J. and Park, J.D. (2013) Evaluation of factors associated with cadmium exposure and kidney function in the general population. Environ. Toxicol., 28, 563-570.

12. Suwazono, Y., Nogawa, K., Uetani, M., Miura, K., Sakata, K., Okayama, A., Ueshima, H., Stamler, J. and Nakagawa, H. (2011) Application of hybrid approach for estimating the benchmark dose of urinary cadmium for adverse renal effects in the general population of Japan. J. Appl. Toxicol., 31, 8993.

13. Kim, Y.D., Yim, D.H., Eom, S.Y., Moon, S.I., Park, C.H., Kim, G.B., Yu, S.D., Choi, B.S., Park, J.D. and Kim, H. (2014) Differences in the susceptibility to cadmium-induced renal tubular damage and osteoporosis according to sex. Environ. Toxicol. Pharmacol., 38, 272-278.

14. Kim, Y.D., Yim, D.H., Eom, S.Y., Moon, S.I., Park, C.H., Kim, G.B., Yu, S.D., Choi, B.S., Park, J.D. and Kim, H. (2015) Temporal changes in urinary levels of cadmium, Nacetyl-beta-d-glucosaminidase and beta2-microglobulin in individuals in a cadmium-contaminated area. Environ. Toxicol. Pharmacol., 39, 35-41.

15. Nishijo, M., Suwazono, Y., Ruangyuttikarn, W., Nambunmee, K., Swaddiwudhipong, W., Nogawa, K. and Nakagawa, H. 
(2014) Risk assessment for Thai population: benchmark dose of urinary and blood cadmium levels for renal effects by hybrid approach of inhabitants living in polluted and non-polluted areas in Thailand. BMC Public Health, 14, 702.

16. Wang, G. and Fowler, B.A. (2008) Roles of biomarkers in evaluating interactions among mixtures of lead, cadmium and arsenic. Toxicol. Appl. Pharmacol., 233, 92-99.

17. Navas-Acien, A., Tellez-Plaza, M., Guallar, E., Muntner, P., Silbergeld, E., Jaar, B. and Weaver, V. (2009) Blood cadmium and lead and chronic kidney disease in US adults: a joint analysis. Am. J. Epidemiol., 170, 1156-1164.

18. Trzeciakowski, J.P., Gardiner, L. and Parrish, A.R. (2014) Effects of environmental levels of cadmium, lead and mercury on human renal function evaluated by structural equation modeling. Toxicol. Lett., 228, 34-41.

19. Hambach, R., Lison, D., D’Haese, P.C., Weyler, J., De Graef, E., De Schryver, A., Lamberts, L.V. and van Sprundel, M. (2013) Co-exposure to lead increases the renal response to low levels of cadmium in metallurgy workers. Toxicol. Lett., 222, 233-238.

20. Lim, J.A., Kwon, H.J., Ha, M., Kim, H., Oh, S.Y., Kim, J.S.,
Lee, S.A., Park, J.D., Hong, Y.S., Sohn, S.J., Pyo, H., Park, K.S., Lee, K.G., Kim, Y.D., Jun, S. and Hwang, H.S. (2015) Korean research project on the integrated exposure assessment of hazardous substances for food safety. Environ. Health Toxicol., 30, e2015004.

21. Barbier, O., Jacquillet, G., Tauc, M., Cougnon, M. and Poujeol, P. (2005) Effect of Heavy Metals on, and Handling by, the Kidney. Nephron Physiol., 99, 105-110.

22. Garçon, G., Leleu, B., Marez, T., Zerimech, F., Haguenoer, J.M., Furon, D. and Shirali, P. (2007) Biomonitoring of the adverse effects induced by the chronic exposure to lead and cadmium on kidney function: usefulness of alpha-glutathione S-transferase. Sci. Total Environ., 377, 165-172.

23. Shelley, R., Kim, N.S., Parsons, P., Lee, B.K., Jaar, B., Fadrowski, J., Agnew, J., Matanoski, G.M., Schwartz, B.S., Steuerwald, A., Todd, A., Simon, D. and Weaver, V.M. (2012) Associations of multiple metals with kidney outcomes in lead workers. Occup. Environ. Med., 69, 727-735.

24. Korean Ministry of Food and Drug Safety. (2012) A study on the integrated exposure to hazardous materials for safety control. 